\title{
Overexpression of 6-phosphofructo-2-kinase/fructose- 2,6-bisphosphatase in mouse liver lowers blood glucose by suppressing hepatic glucose production
}

\author{
Chaodong Wu, ${ }^{1}$ David A. Okar, ${ }^{1}$ Christopher B. Newgard, ${ }^{2}$ and Alex J. Lange ${ }^{1}$ \\ ${ }^{1}$ Department of Biochemistry, Molecular Biology and Biophysics, Medical School, University of Minnesota, Minneapolis, \\ Minnesota, USA \\ ${ }^{2}$ Departments of Biochemistry and Internal Medicine, Touchstone Center for Diabetes Research, \\ University of Texas Southwestern Medical Center, Dallas, Texas, USA
}

Address correspondence to: Alex J. Lange, Department of Biochemistry, Molecular Biology and Biophysics, Medical School, University of Minnesota, 6-155 Jackson Hall, 321 Church Street SE, Minneapolis, Minnesota 55455, USA.

Phone: (612) 626-4502; Fax: (612) 625-5476; E-mail: lange024@tc.umn.edu.

Received for publication October 12, 2000, and accepted in revised form November 14, 2000.

Hepatic 6-phosphofructo-2-kinase/fructose-2,6-bisphosphatase is an important regulatory enzyme of glucose metabolism. By controlling the level of fructose-2,6-bisphosphate, an allosteric activator of the glycolytic enzyme 6-phosphofructo-1-kinase and an inhibitor of the gluconeogenic enzyme fructose1,6-bisphosphatase, 6-phosphofructo-2-kinase/fructose-2,6-bisphosphatase regulates hepatic glucose output. We studied the effects of adenovirus-mediated overexpression of this enzyme on hepatic glucose metabolism in normal or diabetic mice. These animals were treated with virus encoding either wildtype or bisphosphatase activity-deficient 6-phosphofructo-2-kinase/fructose-2,6-bisphosphatase. Seven days after virus injection, hepatic fructose-2,6-bisphosphate levels increased significantly in both normal and diabetic mice, with larger increases observed in animals with overexpression of the mutant enzyme. Blood glucose levels in normal mice overexpressing either enzyme were lowered, accompanied by increased plasma lactate, triglycerides, and FFAs. Blood glucose levels were markedly reduced in diabetic mice overexpressing the wild-type enzyme, and still more so in mice overexpressing the mutant form of the enzyme. The lower blood glucose levels in diabetic mice were accompanied by partially normalized plasma triglycerides and FFAs, increased plasma lactate, and increased liver glycogen levels, relative to diabetic mice treated with a control adenovirus. Our findings underscore the critical role played by hepatic 6-phosphofructo-2-kinase/fructose-2,6-bisphosphatase in control of fuel homeostasis and suggest that this enzyme may be considered as a therapeutic target in diabetes.

J. Clin. Invest. 107:91-98 (2001).

\section{Introduction}

Since its discovery in rat liver during investigations into the mechanism of glucagon-stimulated gluconeogenesis (1-3), fructose-2,6-bisphosphate $\left(\mathrm{F}-2,6-\mathrm{P}_{2}\right)$ has been characterized as a signaling molecule that helps to control the balance between glycolytic and gluconeogenic pathways in liver (4-6). It is a potent allosteric activator of the glycolytic enzyme 6-phosphofructo-1kinase and an inhibitor of the gluconeogenic enzyme fructose-1,6-bisphosphatase $(1,7,8)$. The bifunctional enzyme, 6-phosphofructo-2-kinase/fructose-2,6-bisphosphatase (6PF-2-K/F-2,6- $\mathrm{P}_{2}$ ase), is the sole catalyst of both synthesis of F-2,6- $\mathrm{P}_{2}$ from fructose-6-phosphate (F-6-P) and ATP and degradation of F-2,6- $\mathrm{P}_{2}$ to F-6-P and inorganic phosphate $(9,10)$.

The kinase and bisphosphatase active sites of 6PF-2$\mathrm{K} / \mathrm{F}-2,6-\mathrm{P}_{2}$ ase are distinct, and the relative activities are determined by dephosphorylation/phosphorylation at Serine-32 (11). The opposing metabolic effects of glucose and glucagon may be understood, at least in part, by their opposite effects on the phosphorylation state of Serine-32, and thereby, the kinase to bisphosphatase activity ratio ( $\mathrm{K} / \mathrm{B}$ ratio). Glucagon promotes phosphorylation of Serine-32 via cAMP-dependent protein kinase, lowering the $\mathrm{K} / \mathrm{B}$ ratio and decreasing hepatic F-2,6- $\mathrm{P}_{2}$. Glucose stimulates dephosphorylation of Serine-32 via xylulose-5-P-dependent protein phosphatase, increasing the K/B ratio and raising hepatic F-2,6- $\mathrm{P}_{2}$ (12-14). The double mutant bifunctional enzyme, used in the present studies, possesses a mutation of Serine32 to Alanine, which prevents cAMP-dependent phosphorylation (15), and a mutation of Histidine-258 to Alanine, which diminishes bisphosphatase activity (16). Therefore, the double mutant 6PF-2-K/F-2,6- $\mathrm{P}_{2}$ ase has a very high $\mathrm{K} / \mathrm{B}$ ratio and should enhance glycolysis and inhibit gluconeogenesis by increasing hepatic $\mathrm{F}-2,6-\mathrm{P}_{2}$. In rat hepatoma-derived FAO cells, adenovirus-mediated overexpression of wild-type 6PF-2$\mathrm{K} / \mathrm{F}-2,6-\mathrm{P}_{2}$ ase led to a decrease in F-2,6- $\mathrm{P}_{2}$ levels, whereas overexpression of the double mutant rat liver bifunctional enzyme led to an increase in this biofactor (17). Elevated F-2,6- $\mathrm{P}_{2}$ levels caused an increase in glycolytic flux and a decrease in gluconeogenesis, whereas decreased levels of F-2,6- $\mathrm{P}_{2}$ had the opposite effect (17). 


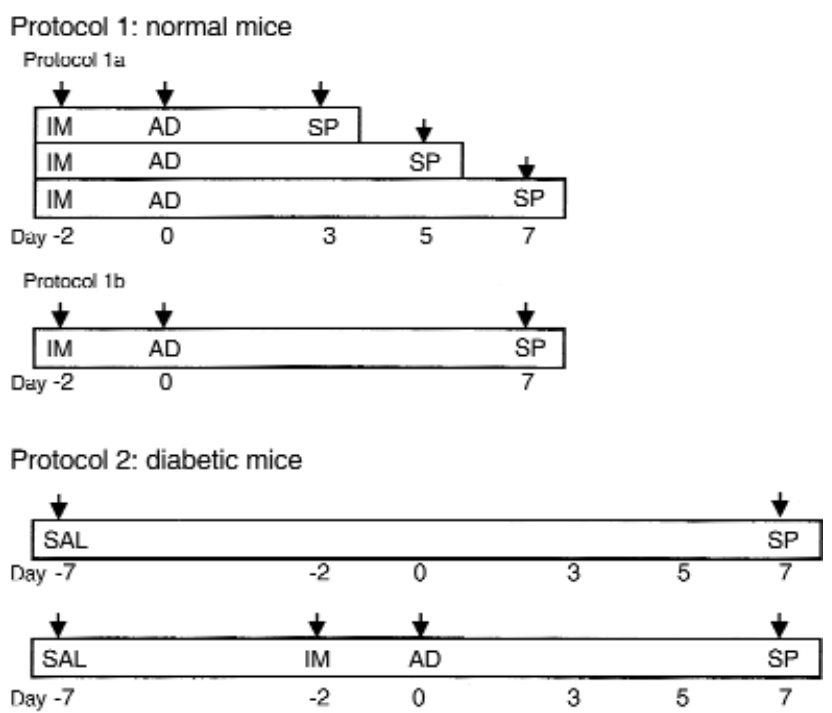

Figure 1

Protocols for treatment of normal mice and STZ-induced diabetic mice with adenovirus. Protocol 1 was used for normal mice treated with adenovirus. Protocol 1a: Time course of overexpression of double mutant 6PF-2-K/F-2,6- $\mathrm{P}_{2}$ ase in normal mice. Immunosuppressant injection (IM) started at day -2 . Samples were collected (SP) on day 0 (no adenovirus infusion) and days 3, 5, and 7 (after adenovirus infusion; $n=2)$. Protocol 1b: Normal mice were divided into three groups $(n=6)$ and treated with different adenovirus. IM was started on day -2 ; adenovirus $(A D)$ was infused on day 0 . Samples were collected (SP) on day 7. Protocol 2 was used for diabetogenesis and adenovirus infusion. Saline control mice $(n=6)$ only received citrate buffer $(S A L)$ on day -7 , and samples were collected on day 7. Mice were made diabetic by STZ injection on day -7. IM started on day -2 , and AD was given on day 0 . Samples were collected (SP) on day $7(n=6)$.

The ability of liver to maintain a balance between the uptake and release of glucose plays a critical role in maintenance of blood glucose homeostasis $(18,19)$. In partially pancreatectomized diabetic rats or diabetic subjects (IDDM and NIDDM), hepatic glucose production (HGP) is markedly increased $(20,21)$, contributing to development of hyperglycemia $(22,23)$. These observations suggest that blood glucose can be regulated by manipulation of HGP. Owing to the effect of 6PF-2$\mathrm{K} / \mathrm{F}-2,6-\mathrm{P}_{2}$ ase on hepatic F-2,6- $\mathrm{P}_{2}$ content, we postulated that overexpression of a kinase-dominant $6 \mathrm{PF}-2-\mathrm{K} / \mathrm{F}$ 2,6- $\mathrm{P}_{2}$ ase would reduce HGP by enhancing glycolysis and inhibiting gluconeogenesis, thereby, lowering blood glucose in diabetes (24). In this study, we have used recombinant adenovirus to express wild-type or double mutant rat liver $6 \mathrm{PF}-2-\mathrm{K} / \mathrm{F}-2,6-\mathrm{P}_{2}$ ase to high level relative to the naturally occurring enzyme (overexpression) in liver of normal and streptozotocin-induced diabetic mice. This maneuver is shown to have wide-ranging effects on fuel homeostasis, including substantial lowering of blood glucose levels in the diabetic animals.

\section{Methods}

Recombinant adenovirus. Adenovirus containing the cDNA encoding either wild-type (Ad-Bif-WT) or mutant rat liver 6PF-2-K/F-2,6- $\mathrm{P}_{2}$ ase (Ad-Bif-DM) was prepared as described previously (17). An adenovirus vector coding for Escherichia coli $\beta$ galactosidase (Ad-gal) was used as a control (25).

Animal experiments. Male 10- to 12-week old 129J mice were obtained from The Jackson Laboratory (Bar Harbor, Maine, USA). Animal experiments were done following different protocols as shown in Figure 1. Protocol 1: Normal mice were treated with adenovirus. Immunosuppressants (cyclosporin A at $8 \mathrm{mg} / \mathrm{kg} / \mathrm{d}$ and prednisone at $2.5 \mathrm{mg} / \mathrm{kg} / \mathrm{d}$ ) were used to prevent immune responses to adenovirus. The cyclosporin $\mathrm{A}$ dose was doubled on the day of virus infusion and then changed to maintenance dose of $4 \mathrm{mg} / \mathrm{kg} / \mathrm{d}$ for 5 more days. Prednisone was discontinued on day 3 after adenovirus infusion. Administration of cyclosporin A and Prednisone at those doses had no effect on any metabolic parameters (26). Six of eight immunosuppressant-treated mice were injected with $0.3 \mathrm{ml} 1 \times 10^{10}-5 \times 10^{10} \mathrm{pfu} / \mathrm{ml}$ of Ad-Bif-DM via tail vein, and liver tissue was collected at different time points (as in Figure 1; protocol 1a) for Western blot analysis and kinase activity assay to determine the time course of enzyme expression. The other two mice received no virus and served as control. On the basis of the time course of enzyme overexpression and activity, as well as previous studies $(26,27)$, we developed the experiments in protocols $1 \mathrm{~b}$ and 2 . Under protocol $1 \mathrm{~b}$, 18 normal mice were divided into three groups. Mice in each group were infused with same amount $(0.3 \mathrm{ml} 1 \times$ $10^{10}-5 \times 10^{10} \mathrm{pfu} / \mathrm{ml}$ ) of Ad-gal, Ad-Bif-WT, or Ad-BifDM. Samples of both blood and tissues were collected for analyses of bifunctional enzyme and metabolite levels at day 7. Protocol 2: Twenty-four mice were divided into four groups: saline control mice, streptozotocininduced (STZ-induced) diabetic mice treated with Adgal, STZ-induced diabetic mice treated with Ad-Bif-WT, or STZ-induced diabetic mice treated with Ad-Bif-DM. The latter three groups of mice were made diabetic by a single intraperitoneal injection of $3.5 \mathrm{mg} \mathrm{STZ}$ (dissolved in $100 \mathrm{mM}$ citrate [pH 4.5] containing $150 \mathrm{mM} \mathrm{NaCl}$ ). Saline control mice were injected only with citrate buffer. Five days later, all STZ-injected mice were confirmed to be diabetic by measurement of nonfasted blood glucose levels of $\geq 13.9 \mathrm{mM}(250 \mathrm{mg} / \mathrm{dl})$. The diabetic mice were then infused with adenovirus. Immunosuppressant treatment and adenovirus infusion were as described for protocol 1. Nonfasted blood glucose of the diabetic mice were monitored on days $-7,-2,0,3,5$, and 7 (as in Figure 1; protocol 2). Nonfasted blood glucose of the six saline control mice was monitored at the same times as the diabetic mice. All mice were sacrificed for blood and tissue sample collection at day 7. Blood samples were collected from the tail vein, and $0.1 \mathrm{M}$ EDTA was used as anticoagulant. Plasma was obtained by centrifugation of collected blood (27).

The study protocols were reviewed and approved by the Institutional Animal Care and Use Committees of the University of Minnesota. 
a

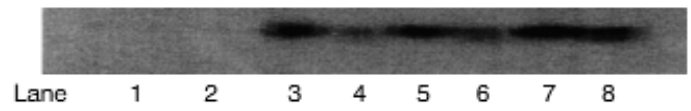

b

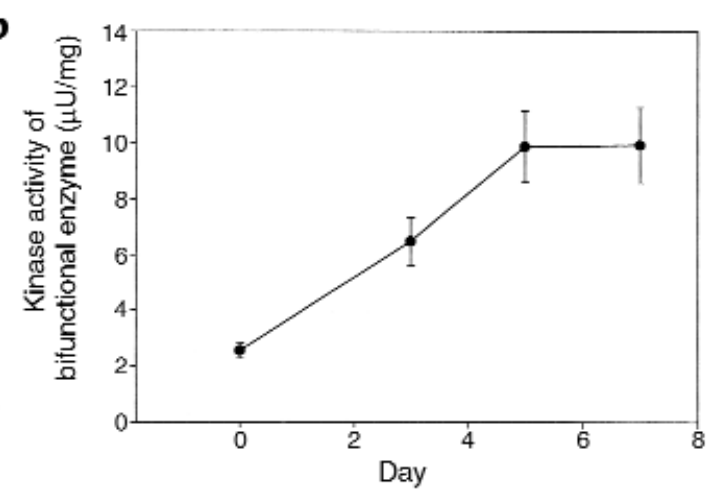

Figure 2

Time course of 6PF-2-K/F-2,6- $\mathrm{P}_{2}$ ase overexpression in the liver of normal mice treated with Ad-Bif-DM. (a) Western blot analysis of 6PF2-K/F-2,6- $\mathrm{P}_{2}$ ase. 6PF-2-K/F-2,6- $\mathrm{P}_{2}$ ase was extracted from fresh liver of normal mice on day 0 (without adenovirus infusion, lanes 1 and 2), day 3 (lanes 3 and 4), day 5 (lanes 5 and 6), and day 7 (lane 7 and 8), from mice that had received Ad-Bif-DM infusion. Concentration of extracted protein was measured by the BCA method. Equal amounts of extracted protein $(100 \mu \mathrm{g})$ were loaded in each lane for SDS-PAGE and transferred to PVDF membrane by electrophoresis. Anti-rat liver 6PF-2K/F-2,6- $\mathrm{P}_{2}$ ase polyclonal antibody served as primary antibody at 1:1,000 dilution. (b) A total of 50 or $100 \mu \mathrm{g}$ extracted protein was used for kinase activity assay by catalyzing synthesis of F-2,6- $\mathrm{P}_{2}$ from $25 \mathrm{mM} \mathrm{F-6-P.}$

RNA analysis. Total RNA was extracted from fresh liver tissue with Stat- 60 following the protocol of the manufacturer (TEL-TEST B Inc., Friendswood, Texas, USA). Northern blots were performed as reported previously $(17,28)$. A 1.4-kb cDNA of rat liver 6PF-2K/F-2,6- $\mathrm{P}_{2}$ ase was labeled with $\alpha-{ }^{32} \mathrm{P}-\mathrm{dCTP}$ and used as probe.

Enzyme analysis. 6PF-2-K/F-2,6- $\mathrm{P}_{2}$ ase was extracted from fresh liver tissue by homogenizing in buffer $\mathrm{H}(20$ mM TES, $1 \mathrm{mM}$ DTT, $100 \mathrm{mM} \mathrm{KCl}, 5 \mathrm{mM}$ EDTA, 5 mM EGTA [pH 7.8], $1.2 \mathrm{mM}$ PMSF, $2.5 \mathrm{mg} / \mathrm{L}$ leupeptin). After precipitation with $40 \%$ PEG, the pellet was dissolved in buffer B (20 mM TES, $1 \mathrm{mM}$ DTT, 100 $\mathrm{mM} \mathrm{KCl}, 0.1 \mathrm{mM}$ EDTA [pH 7.5], 0.5 mM PMSF, 2.5 $\mathrm{mg} / \mathrm{L}$ leupeptin). The concentration of extracted protein was measured by the BCA method (Pierce Chemical Co., Rockford, Illinois, USA). Equal amounts of extracted protein $(100 \mu \mathrm{g})$ were used for Western blots as reported previously (17). Rabbit anti-rat liver 6PF-2$\mathrm{K} / \mathrm{F}-2,6-\mathrm{P}_{2}$ ase serum was used as primary antibody at a 1:1,000 dilution. The blot was followed by a 1:10,000 dilution of goat anti-rabbit horseradish peroxidaseconjugated secondary antibody kit (ECL; Amersham Life Science, Buckinghamshire, United Kingdom).

$6 P F-2-K / F-2,6-P_{2}$ ase activities. The maximal velocity of $6 \mathrm{PF}-2-\mathrm{K}$ was assayed by the production of F-2,6- $\mathrm{P}_{2}$. A total of $80 \mu \mathrm{l}(50$ or $100 \mu \mathrm{g})$ of extracted protein was incubated in $20 \mu \mathrm{l}$ buffer B containing $25 \mathrm{mM}$ F-6-P, 25 $\mathrm{mM}$ ATP, $50 \mathrm{mM} \mathrm{MgCl}$ and $25 \mathrm{mM} \mathrm{KH}_{2} \mathrm{PO}_{4}$ for 20 minutes at $37^{\circ} \mathrm{C}(5)$. The maximal velocity of F-2,6$\mathrm{P}_{2}$ ase was assayed by measuring the consumption of F-2,6-P . A total of $20 \mu \mathrm{l}(50 \mathrm{or} 100 \mu \mathrm{g})$ of extracted protein was incubated in $80 \mu \mathrm{l}$ buffer containing $0.5 \mu \mathrm{M}$ F-2,6- $\mathrm{P}_{2}, 50 \mathrm{mM} \mathrm{MgCl}_{2}, 5 \mathrm{mM}$ EGTA, $1 \mathrm{mM}$ DTT, 1\% Polyethylene glycol, $100 \mathrm{mM}$ HEPES (pH 7.5), $0.5 \mu \mathrm{M}$ NADP, 0.4 units of desalted glucose-6-phosphate dehydrogenase, and 1 unit of phosphoglucose isomerase for 20 minutes at $37^{\circ} \mathrm{C}(29)$. Determination of F-2,6- $\mathrm{P}_{2}$ was the same as described below.

Hepatic F-2,6- $P_{2}$ content. F-2,6- $\mathrm{P}_{2}$ was extracted from fresh liver tissue in $10-20$ volumes of $50 \mathrm{mM} \mathrm{NaOH}$ and kept at $80^{\circ} \mathrm{C}$ for 5 minutes. The extract was cooled and neutralized at $0^{\circ} \mathrm{C}$ by addition of ice-cold $1 \mathrm{M}$ acetic acid in presence of $20 \mathrm{mM}$ HEPES. After centrifugation at $8,000 \mathrm{~g}$ for 10 minutes, supernatant was collected and assayed for F-2,6- $\mathrm{P}_{2}$ by the 6-phosphofructo-1-kinase activation method (30).

Blood metabolites. Blood glucose was measured by the glucose oxidase method (Precision glucometer; Medisense Inc., Waltham, Massachusetts, USA). Plasma levels of lactate, pyruvate, triglycerides (TGs) were meas-

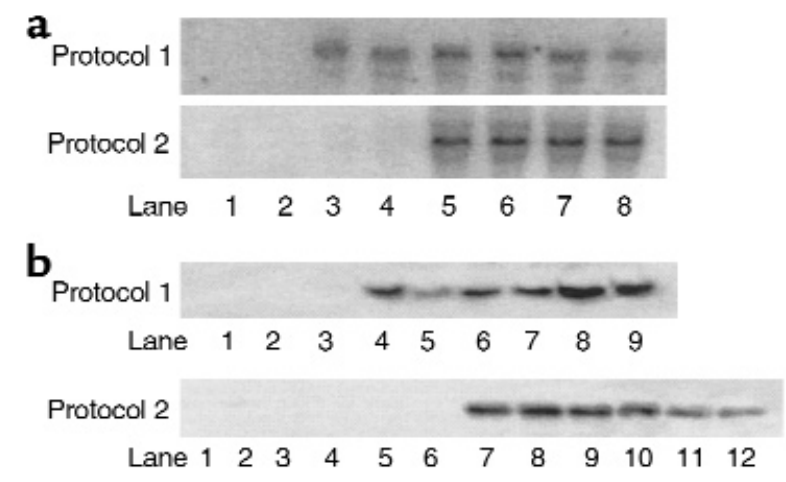

\section{Figure 3}

Northern and Western blot analyses of $6 \mathrm{PF}-2 \mathrm{~K} / \mathrm{F}-2,6-\mathrm{P}_{2}$ ase overexpression. (a) Northern blot analysis of $6 \mathrm{PF}-2 \mathrm{~K} / \mathrm{F}-2,6-\mathrm{P}_{2}$ ase mRNA. Total RNA was extracted from fresh liver of all mice on day 7 after adenovirus infusion. For both protocols, only three animals of each group were chosen, without bias, and used for Northern blot analyses. A total of $30 \mu \mathrm{g}$ RNA was loaded in each lane for electrophoresis. In protocol 1, samples were from normal mice treated with adenovirus (two representative animals of Ad-gal group, lanes 1 and 2; three animals of Ad-Bif-WT group, lanes 3-5; and three animals of Ad-Bif-DM group, lanes 6-8). In protocol 2, samples were from saline control mice and STZ-induced diabetic mice treated with adenovirus (two representative animals of each group are shown in blots). Saline control group, lanes 1 and 2; STZ-Ad-gal group, lanes 3 and 4; STZ-AdBif-WT group, lanes 5 and 6; and STZ-Ad-Bif-DM group, lanes 7 and 8). (b) Western blot analysis of 6PF-2K/F-2,6- $\mathrm{P}_{2}$ ase protein. Extracted protein was prepared from fresh liver tissue of mice sacrificed on day 7 after adenovirus infusion. For both protocols, only three animals of each group were chosen, without bias, and used for Western blot analyses. Concentration of extracted protein was measured by the BCA method. Equal amounts of extracted protein $(100 \mu \mathrm{g})$ were used for electrophoresis. In protocol 1, samples were from the Ad-gal group (lanes 1-3), Ad-Bif-WT group (lanes 4-6), and Ad-Bif-DM group (lanes 7-9). In protocol 2, samples were from the saline control group (lanes 1-3), STZ-Ad-gal group (lanes 4-6), STZ-Ad-Bif-WT group (lanes 7-9), and STZ-Ad-Bif-DM group (lanes 10-12). 
Table 1

Liver 6PF-2-K/F-2,6- $\mathrm{P}_{2}$ ase activities and F-2,6- $\mathrm{P}_{2}$ content of normal mice treated with adenovirus

\begin{tabular}{llcll}
\hline & $\begin{array}{c}\text { Kinase } \\
(\mu \mathrm{U} / \mathrm{mg})\end{array}$ & $\begin{array}{c}\text { Bisphosphatase } \\
(\mu \mathrm{U} / \mathrm{mg})\end{array}$ & K/B ratio & $\begin{array}{c}\mathrm{F}-2,6-\mathrm{P}_{2} \\
(\mathrm{nmol} / \mathrm{g})\end{array}$ \\
Ad-gal & $2.57 \pm 0.29$ & $1.49 \pm 0.24$ & $1.81 \pm 0.18$ & $3.37 \pm 0.69$ \\
Ad-Bif-WT & $9.25 \pm 0.71^{\mathrm{A}}$ & $2.55 \pm 0.12^{\mathrm{A}}$ & $3.65 \pm 0.26^{\mathrm{A}}$ & $6.26 \pm 0.77^{\mathrm{C}}$ \\
Ad-Bif-DM & $9.09 \pm 0.78^{\mathrm{A}}$ & $1.90 \pm 0.13^{\mathrm{B}}$ & $4.79 \pm 0.28^{\mathrm{A}, \mathrm{D}}$ & $8.78 \pm 0.77^{\mathrm{A}, \mathrm{D}}$
\end{tabular}

$6 \mathrm{PF}-2-\mathrm{K} / \mathrm{F}-2,6-\mathrm{P}_{2}$ ase and $\mathrm{F}-2,6-\mathrm{P}_{2}$ were extracted from liver of normal mice treated with adenovirus ( 7 days after treatment). Data are mean $\pm \operatorname{SEM}(n=6)$. ${ }^{A} P<0.01$ versus $\mathrm{Ad}-$ gal. ${ }^{B} P<0.01$ versus Ad-Bif-WT. ${ }^{C} P<0.05$ versus Ad-gal. ${ }^{D} P<0.05$ versus Ad-Bif-WT. in Ad-Bif-WT group, and is reflected in a lower $\mathrm{K} / \mathrm{B}$ ratio in the Ad-Bif-WT compared with that in the Ad-Bif-DM group $(P<0.05)$. Hepatic F-2,6- $\mathrm{P}_{2}$ content of mice treated with either Ad-Bif-WT or Ad-Bif-DM was increased 1.9- to 2.6-fold, respectively, compared with the Adgal group. Therefore, the higher $\mathrm{K} / \mathrm{B}$ ratio of mutant bifunctional enzyme in Ad-BifDM-treated mice resulted in the higher levels of hepatic F-2,6- $\mathrm{P}_{2}$.

In protocol 2, diabetes was induced by STZ injection, followed by treatment of animals ured with $5 \mu$ l plasma by kits from Sigma Chemical Co. (St. Louis, Missouri, USA). Plasma FFAs were assayed with $15 \mu \mathrm{l}$ plasma by the kit from Boehringer Mannheim GmbH (Mannheim, Germany). All procedures were performed according to the directions provided by the manufacturers.

Liver metabolites and glycogen. Liver homogenates were prepared by standard methods (31). The concentration of metabolites in liver homogenate was assayed as described earlier here. For liver glycogen measurement, amyloglucosidase was used to degrade glycogen, and the glucose formed was determined via the glucose oxidase method (32).

\section{Results}

Overexpression of the bifunctional enzyme in mouse liver. Western blot analyses and kinase assays showed overexpression of double mutant $6 \mathrm{PF}-2-\mathrm{K} / \mathrm{F}-2,6-\mathrm{P}_{2}$ ase in the liver of normal mice started within 3 days after adenovirus infusion (Figure 2). The enzyme overexpression was evident from day 3 to day 7 , and the enzyme activity was the same on day 5 and day 7 . This protocol is also consistent with previous studies (26, $27)$, in which the duration of experiments was limited to 5 or 7 days after adenovirus infusion. As shown in Figure 3, $a$ and $b$, overexpression of rat liver 6PF-2$\mathrm{K} / \mathrm{F}-2,6-\mathrm{P}_{2}$ ase was evident on day 7 by substantially increased mRNA and protein levels, respectively, in both normal and STZ-induced diabetic mice treated with Ad-Bif-WT or Ad-Bif-DM.

Enzyme activities and $F-2,6-P_{2}$ content. The enzyme activities, $\mathrm{K} / \mathrm{B}$ ratio, and hepatic F-2,6- $\mathrm{P}_{2}$ contents for normal mice in protocol 1 are shown in Table 1 . The kinase activities of $6 \mathrm{PF}-2 \mathrm{~K} / \mathrm{F}-2,6-\mathrm{P}_{2}$ ase were increased significantly in both Ad-BifWT and Ad-Bif-DM groups $(9.3 \pm 0.7$ and $9.1 \pm 0.8 \mu \mathrm{U} / \mathrm{mg}, P<0.01$ versus Ad-gal group, $2.6 \pm 0.3 \mu \mathrm{U} / \mathrm{mg}$ ). Furthermore, bisphosphatase activity in Ad-Bif-WT group increased significantly $(2.6 \pm 0.1 \mu \mathrm{U} / \mathrm{mg}, P<0.01$ vs. Ad-gal group, $1.5 \pm 0.2 \mu \mathrm{U} / \mathrm{mg}$ ), whereas the increase in the Ad-Bif-DM group was not significant $(1.9 \pm 0.13$ $\mu \mathrm{U} / \mathrm{mg})$. This is exactly as expected based on the design of the Ad-Bif-DM and the intact bisphosphatase activity

\section{Table 2}

with Ad-Bif-WT or Ad-Bif-DM. The effects of these treatments on hepatic 6PF-2-K/F-2,6- ${ }_{2}$ ase and F-2,6$\mathrm{P}_{2}$ content are shown in Table 2 . The kinase activity decreased dramatically in the STZ-Ad-gal group (1.76 $\pm 0.04 \mu \mathrm{U} / \mathrm{mg}, P<0.01$ versus saline control group; $4.32 \pm 0.49 \mu \mathrm{U} / \mathrm{mg}$ ), whereas it increased in both STZ-Ad-Bif-WT and STZ-Ad-Bif-DM groups $(10.7 \pm 0.9$ and $15.0 \pm 0.5 \mu \mathrm{U} / \mathrm{mg}, P<0.01$ versus saline control group). The bisphosphatase activity also increased in both STZ-Ad-Bif-WT and STZ-Ad-BifDM groups $(5.0 \pm 0.4$ and $4.0 \pm 0.2 \mu \mathrm{U} / \mathrm{mg}, P<0.01$ versus saline control group; $2.52 \pm 0.23 \mu \mathrm{U} / \mathrm{mg}$ ). These changes resulted in a significant decrease of $\mathrm{K} / \mathrm{B}$ ratio in the STZ-Ad-gal group $(0.5 \pm 0.1, P<0.01$ versus saline control group; $1.7 \pm 0.1)$ and an increase in the STZ-Ad-Bif-DM group $(3.8 \pm 0.3, P<0.01$ versus saline control group). Consequently, hepatic F-2,6- $\mathrm{P}_{2}$ content in the STZ-Ad-gal group fell to $10 \%$ of that in the saline control group $(0.6 \pm 0.05 \mathrm{nmol} / \mathrm{g}, P<0.01$ versus saline control group) and increased 1.7- or 3.1-fold in the STZ-Ad-Bif-WT or STZ-Ad-Bif-DM groups, respectively $(8.8 \pm 1.0 \mathrm{nmol} / \mathrm{g}$ or $16.4 \pm 0.7 \mathrm{nmol} / \mathrm{g}$, $P<0.05$ or $P<0.01$ versus saline control group). As in the normal mice, the higher $\mathrm{K} / \mathrm{B}$ ratio in the STZ-AdBif-DM group $(3.8 \pm 0.3)$ generated a higher hepatic F-2,6- $\mathrm{P}_{2}$ content than that in the STZ-Ad-Bif-WT group $(2.2 \pm 0.3, P<0.01)$.

Changes of blood glucose. For mice in protocol 1b, levels of blood glucose were lowered in both the Ad-Bif-WT group and the Ad-Bif-DM group (Figure 4a) 7 days after adenovirus infusion. There was a $24 \%$ decrease in the Ad-Bif-WT group (to $4.5 \pm 0.2 \mathrm{mM}$ ) and a $39 \%$ decrease in the Ad-Bif-DM group (to $3.8 \pm 0.2 \mathrm{mM}$ ).
Liver 6PF-2-K/F-2,6- $\mathrm{P}_{2}$ ase activities and F-2,6- $\mathrm{P}_{2}$ content of saline control mice and diabetic mice treated with adenovirus

\begin{tabular}{lcccc}
\hline & $\begin{array}{c}\text { Kinase } \\
(\mu \mathrm{U} / \mathrm{mg})\end{array}$ & $\begin{array}{c}\text { Bisphosphatase } \\
(\mu \mathrm{U} / \mathrm{mg})\end{array}$ & $\mathrm{K} / \mathrm{B}$ ratio & $\begin{array}{c}\mathrm{F}-2,6-\mathrm{P}_{2} \\
(\mathrm{nmol} / \mathrm{g})\end{array}$ \\
Saline control & $4.32 \pm 0.49$ & $2.52 \pm 0.23$ & $1.71 \pm 0.05$ & $5.25 \pm 0.64$ \\
STZ-Ad-gal & $1.76 \pm 0.04^{\mathrm{A}}$ & $3.48 \pm 0.53$ & $0.53 \pm 0.08^{\mathrm{A}}$ & $0.58 \pm 0.05^{\mathrm{A}}$ \\
STZ-Ad-Bif-WT & $10.74 \pm 0.86^{\mathrm{A}, \mathrm{C}}$ & $4.96 \pm 0.40^{\mathrm{A}}$ & $2.19 \pm 0.25^{\mathrm{C}}$ & $8.76 \pm 0.97^{\mathrm{B}, \mathrm{C}}$ \\
STZ-Ad-Bif-DM & $15.00 \pm 0.46^{\mathrm{A}, \mathrm{C}, \mathrm{D}}$ & $4.01 \pm 0.17^{\mathrm{A}}$ & $3.77 \pm 0.29^{\mathrm{A}, \mathrm{C}, \mathrm{D}}$ & $16.44 \pm 0.74^{\mathrm{A}, \mathrm{C}, \mathrm{E}}$
\end{tabular}

6PF-2-K/F-2,6- $\mathrm{P}_{2}$ ase and $\mathrm{F}-2,6-\mathrm{P}_{2}$ were extracted from liver of saline control mice, and from liver of STZ-induced diabetic mice treated with adenovirus ( 7 days after adenovirus infusion for both groups). Only three animals of each group were chosen, without bias, and used for the measurements. Data are mean $\pm \operatorname{SEM}(n=3)$. ${ }^{A} P<0.01$ versus saline control. ${ }^{B} P<0.05$ versus saline control. ${ }^{C} P<0.01$ versus STZ-Ad-gal. ${ }^{\mathrm{D}} P<0.05$ versus STZ-Ad-Bif-WT. ${ }^{\mathrm{E}} P<0.01$ versus STZ-Ad-Bif-WT. 

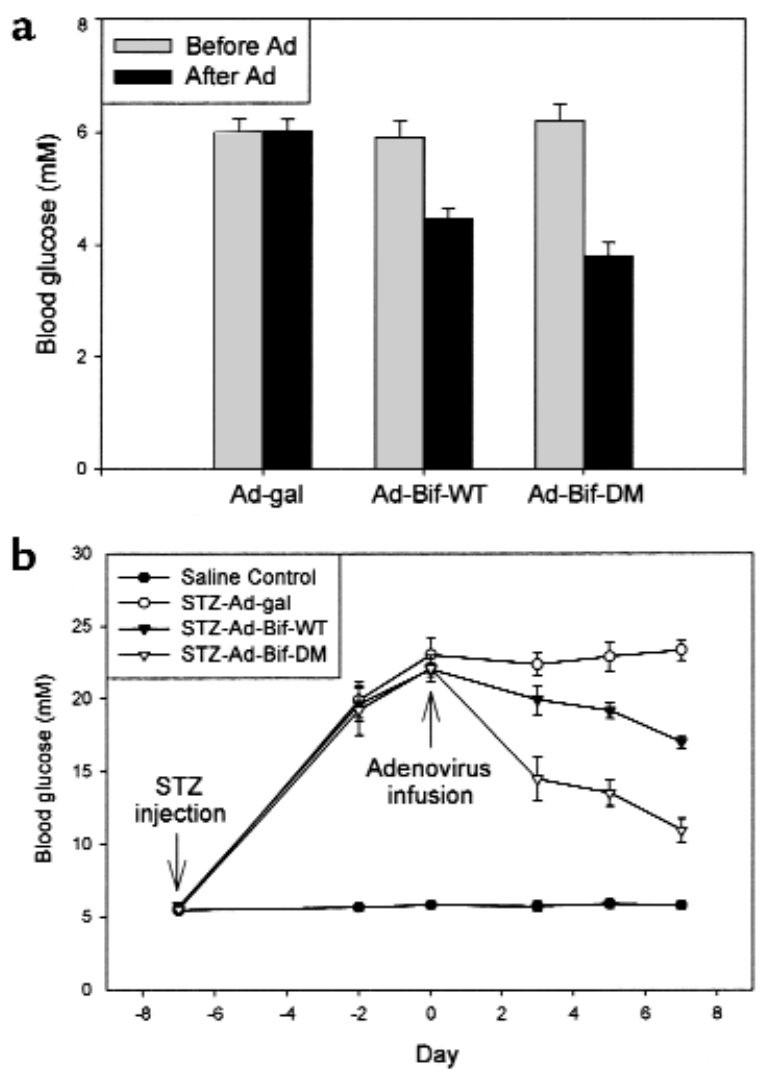

\section{Figure 4}

Changes of blood glucose levels in normal and diabetic mice treated with adenovirus. (a) Normal mice were treated with adenovirus. Blood glucose was monitored on day 0 (before adenovirus infusion) and day 7 (after adenovirus infusion). The levels of blood glucose in both the Ad-Bif-WT and the Ad-Bif-DM groups decreased significantly $(P<0.01$ versus before adenovirus infusion or Ad-gal group). Decreases in blood glucose levels in the Ad-Bif-DM group were much greater than those in the Ad-Bif-WT group $(P<0.05$; $n=6)$. (b) Saline control and STZ-diabetic mice treated with adenovirus. All mice treated with STZ showed significant increase in levels of blood glucose on day $-2(P<0.01$ versus saline control group). After adenovirus infusion, blood glucose levels fell within 3 days $(P<0.01)$ in the STZ-Ad-Bif-DM group, and within 5 days $(P<0.01)$ in the STZ-Ad-Bif-WT group. By day 7 , levels of blood glucose were decreased $50 \%$ in the STZ-Ad-Bif-DM group and $23 \%$ in the STZ-Ad-Bif-WT group. Decreases in blood glucose levels in the STZ-Ad-Bif-DM group were much greater than those in STZAd-Bif-WT group $(P<0.01 ; n=6)$.

For mice in protocol 2, changes in blood glucose levels are shown in Figure $4 \mathrm{~b}$. All mice treated with STZ were hyperglycemic at day $-2(P<0.01$ versus saline control group). After adenovirus infusion, blood glucose levels dropped from $22.1 \pm 0.9 \mathrm{mM}$ to $14.5 \pm 1.5 \mathrm{mM}$ within 3 days $(P<0.01)$ in the STZ-Ad-Bif-DM group and from $22.0 \pm 0.5 \mathrm{mM}$ to $19.2 \pm 0.5 \mathrm{mM}$ within 5 days $(P<0.01)$ in the STZ-Ad-Bif-WT group. By day 7 , blood glucose levels were decreased $50 \%$ in the STZ-Ad-BifDM group (to $11.0 \pm 0.8 \mathrm{mM}$ ) and $23 \%$ in the STZ-AdBif-WT group (to $17.0 \pm 0.5 \mathrm{mM}$ ). A greater decrease in blood glucose levels was seen in the STZ-Ad-Bif-DM group than in the STZ-Ad-Bif-WT group $(P<0.01)$.
Changes of other plasma metabolites. Treatment of normal mice with adenovirus constructs produced effects on other plasma metabolites. As shown in Table 3, 7 days after adenovirus infusion, levels of plasma TGs and FFAs increased $34 \%$ or $75 \%$, respectively, in the AdBif-WT group and $35 \%$ or $88 \%$, respectively, in the AdBif-DM group ( $P<0.01$ versus Ad-gal group). There were no differences in plasma lactate or pyruvate levels. For the diabetic mice, levels of plasma lactate or pyruvate increased significantly in both the STZ-Ad-Bif-DM and STZ-Ad-Bif-WT groups $(P<0.05$ or $P<0.01$ versus saline control or STZ-Ad-gal group, respectively), as shown in Table 4. In the diabetic STZ-Ad-gal group, the levels of plasma TG and FFA were both increased by threefold relative to the saline control group. However, in the STZ-Ad-Bif-DM group, TG and FFA levels were lowered to $67 \%$ and $66 \%$ of the levels in the diabetic mice, respectively ( $P<0.05$ versus STZ-Ad-gal group). Comparison of these parameters in Ad-gal (from protocol 1) with those of the saline control (from protocol 2) demonstrates that cyclosporin A, prednisone, and Ad-gal had no effect on metabolites.

Changes of liver metabolites and glycogen. Table 5 shows that in normal mice treated with Ad-Bif-DM, levels of liver lactate and TG were increased significantly $(P<0.01$ versus Ad-gal group) 7 days after adenovirus infusion. Furthermore, liver glycogen content was decreased in both the Ad-Bif-WT and Ad-Bif-DM groups $(P<0.05$ versus Ad-gal group). There were no significant differences in liver pyruvate.

In diabetic mice, levels of liver lactate decreased in the STZ-Ad-gal group, whereas they increased significantly in both the STZ-Ad-Bif-DM and STZ-Ad-BifWT groups $(P<0.05$ or $P<0.01$ versus saline control or STZ-Ad-gal group), as shown in Table 6. Content of liver glycogen also decreased dramatically in STZ-Adgal group compared with nondiabetic controls. After adenovirus infusion (Ad-gal, Ad- Ad-Bif-WT, or Ad-Bif$\mathrm{DM})$, liver glycogen content was increased significantly $(P<0.01$ versus STZ-Ad-gal group), although levels were only partially restored to those found in the nondiabetic saline control group $(P<0.01)$. There were no changes in liver pyruvate or TGs.

\section{Discussion}

Recombinant adenovirus has been used to deliver a variety of metabolic enzymes and proteins to the liver of intact rodents $(33,34)$. Overexpression of glucokinase or protein targeting to glycogen are maneuvers

\section{Table 3}

Plasma metabolites of normal mice treated with adenovirus

$\begin{array}{lcccc} & \text { Lac }(\mathrm{mM}) & \operatorname{Pyr}(\mathrm{mM}) & \text { TG }(\mathrm{mM}) & \text { FFA }(\mathrm{mM}) \\ \text { Ad-gal } & 4.43 \pm 0.26 & 0.22 \pm 0.04 & 1.33 \pm 0.08 & 0.72 \pm 0.11 \\ \text { Ad-Bif-WT } & 6.06 \pm 0.71 & 0.30 \pm 0.07 & 1.78 \pm 0.10^{\mathrm{A}} & 1.26 \pm 0.11^{\mathrm{A}} \\ \text { Ad-Bif-DM } & 6.21 \pm 0.89 & 0.30 \pm 0.06 & 1.80 \pm 0.04^{\mathrm{A}} & 1.35 \pm 0.12^{\mathrm{A}}\end{array}$

Plasma metabolites were assayed 7 days after adenovirus infusion. Data are mean $\pm \operatorname{SEM}(n=6) .{ }^{A} P<0.01$ versus Ad-gal. Lac, lactate; Pyr, pyruvate. 
Table 4

Plasma metabolites of saline control mice and diabetic mice treated by adenovirus

\begin{tabular}{lcccc}
\hline & Lac $(\mathrm{mM})$ & Pyr $(\mathrm{mM})$ & TG $(\mathrm{mM})$ & FFA $(\mathrm{mM})$ \\
Saline control & $4.17 \pm 0.20$ & $0.20 \pm 0.02$ & $1.43 \pm 0.11$ & $0.75 \pm 0.13$ \\
STZ-Ad-gal & $4.76 \pm 0.31$ & $0.20 \pm 0.02$ & $4.32 \pm 0.40^{\mathrm{A}}$ & $2.22 \pm 0.19^{\mathrm{A}}$ \\
STZ-Ad-Bif-WT & $6.27 \pm 0.13^{\mathrm{A}, \mathrm{C}}$ & $0.31 \pm 0.05$ & $3.99 \pm 0.64^{\mathrm{A}}$ & $1.70 \pm 0.20^{\mathrm{A}}$ \\
STZ-Ad-Bif-DM & $6.83 \pm 0.58^{\mathrm{A}, \mathrm{D}}$ & $0.37 \pm 0.04^{\mathrm{A}, \mathrm{C}}$ & $2.90 \pm 0.33^{\mathrm{A}, \mathrm{D}}$ & $1.46 \pm 0.19^{\mathrm{B}, \mathrm{D}}$
\end{tabular}

Plasma metabolites were assayed from saline control mice and STZ-induced diabetic mice ( 7 days after adenovirus infusion for both groups). Data are mean $\pm \operatorname{SEM}(n=6) .{ }^{A} P<0.01$ versus saline control. ${ }^{B} P<0.05$ versus saline control. ${ }^{C} P<0.01$ versus STZ-Ad-gal. ${ }^{D} P<0.05$ versus STZ-Ad-gal.

that cause lowering of blood glucose levels in normal rats $(26,35)$, whereas overexpression of the catalytic subunit of glucose-6-phosphatase causes glucose intolerance, mild hyperinsulinemia, and decreased hepatic glycogen levels (27). However, overexpression of glucokinase is expected to increase both glycolysis and glycogen synthesis, whereas overexpression of protein targeting to glycogen should enhance glucose disposal mainly via activation of glycogen synthesis. Thus, the current study was designed to investigate the effect of specific manipulation of more distal steps in hepatic glycolysis, with the expectation that this would specifically impact hepatic glucose production via effects on glycolysis and gluconeogenesis.

In the present study, we have studied the metabolic impact of overexpression an important enzyme of hepatic glucose metabolism, 6PF-2-K/F-2,6- $\mathrm{P}_{2}$ ase, in normal and STZ-treated mice, the latter being a model for IDDM. Seven days after adenovirus infusion, Northern and Western blot analyses confirmed successful overexpression of $6 \mathrm{PF}-2-\mathrm{K} / \mathrm{F}-2,6-\mathrm{P}_{2}$ ase in the liver of both normal mice and diabetic mice. As a result of enzyme overexpression, hepatic F-2,6- $\mathrm{P}_{2}$ levels were increased 1.9- to 2.6-fold in normal mice (relative to Ad-gal group; Table 1) and 1.7- to 3.1-fold in the STZinduced diabetic mice (relative to saline control group; Table 2). These results clearly demonstrated that hepatic F-2,6- $\mathrm{P}_{2}$ content could be manipulated and regulated by adenovirus-mediated overexpression of bifunctional enzyme in vivo.

Overexpression of double mutant 6PF-2-K/F-2,6- $\mathrm{P}_{2}$ ase increased hepatic $\mathrm{F}-2,6-\mathrm{P}_{2}$ content to the same extent as that in FAO cells (17). However, in contrast to the previous in vitro results (17), the overexpression of wild-type 6PF-2-K/F-2,6- $\mathrm{P}_{2}$ ase increased rather than decreased $\mathrm{F}-2,6-\mathrm{P}_{2}$ levels. This in vivo observation likely reflects regulation of $\mathrm{K} / \mathrm{B}$ ratio in response to hormonal and metabolic cues (e.g., insulin/glucagon ratio) that were not replicated in the tissue culture study. This view is supported by observations that in re-fed and insulin-treated rats, elevated hepatic F-2,6- $\mathrm{P}_{2}$ contents are correlated with an increased amount of $6 \mathrm{PF}-2-\mathrm{K} / \mathrm{F}-$ $2,6-\mathrm{P}_{2}$ ase, suggesting that in some situations the amount of enzyme is important in determining F-2,6- $\mathrm{P}_{2}(36)$. In the current studies, even when bisphosphatase activity of overexpressed wild-type enzyme was significantly increased, the kinase activity was increased to a greater extent and, thereby, produced a higher $\mathrm{K} / \mathrm{B}$ ratio. For this reason, overexpression of wild-type $6 \mathrm{PF}-2-\mathrm{K} / \mathrm{F}-2,6-\mathrm{P}_{2}$ ase in vivo caused elevations in hepatic F-2,6- $\mathrm{P}_{2}$ content in both normal and STZ-induced diabetic mice, but to a lesser degree than the double mutant enzyme.

The liver plays an important role in the maintenance of euglycemia through its opposing metabolic pathways of glycolysis and gluconeogenesis, which contribute to both disposal and production of glucose, respectively $(18,19)$. In partially pancreatectomized rats, HGP is markedly increased (20). In IDDM patients, hepatic gluconeogenesis is augmented and rates of hepatic pyruvate oxidation are decreased (37). These findings and others have lead to the proposal that increased HGP is a major cause of hyperglycemia $(22,23)$.

We hypothesized that manipulation of hepatic F-2,6$\mathrm{P}_{2}$ content could be used as a point of intervention to modulate HGP and, consequently, blood glucose levels. Treatment of mice with STZ and infusion of the control Ad-gal virus produced diabetes and a concomitant $90 \%$ decrease in hepatic F-2,6- $\mathrm{P}_{2}$ content, consistent with previous studies $(38,39)$. The lower hepatic F-2,6- $\mathrm{P}_{2}$ content was attributable to decreases in both amount and activity of 6PF-2-K/F-2,6- $\mathrm{P}_{2}$ ase after STZ injection $(36,40,41)$. In previous experiments with STZ-induced diabetic rats, the amount of $6 \mathrm{PF}-2-\mathrm{K} / \mathrm{F}-$ 2,6- $\mathrm{P}_{2}$ ase mRNA was restored to normal by refeeding and insulin administration (36). In our experiments, both normal and STZ-induced diabetic mice showed increased hepatic F-2,6- $\mathrm{P}_{2}$ content after infusion of AdBif-WT or Ad-Bif-DM viruses and concurrent lowering of blood glucose levels. Moreover, blood glucose levels were much lower in normal or STZ-induced diabetic mice treated with Ad-Bif-DM than in those treated with Ad-Bif-WT (Figure 4, a and b). This is as expected because the double mutant $6 \mathrm{PF}-2-\mathrm{K} / \mathrm{F}-2,6-\mathrm{P}_{2}$ ase was designed to have a higher $\mathrm{K} / \mathrm{B}$ ratio compared with the wild-type enzyme and clearly produced higher levels of hepatic F-2,6- $\mathrm{P}_{2}$. These data convincingly indicate that manipulation of hepatic F-2,6- $\mathrm{P}_{2}$ content in vivo can regulate glucose homeostasis.

\section{Table 5}

Liver metabolites of normal mice treated with adenovirus

\begin{tabular}{lccccc}
\hline & Lac $(\mu \mathrm{mol} / \mathrm{g})$ & Pyr $(\mu \mathrm{mol} / \mathrm{g})$ & $\mathrm{TG}(\mu \mathrm{mol} / \mathrm{g})$ & FFA $(\mu \mathrm{mol} / \mathrm{g})$ & $\mathrm{Gly}(\mathrm{mg} / \mathrm{g})$ \\
Ad-gal & $5.33 \pm 0.58$ & $0.27 \pm 0.04$ & $50.97 \pm 1.72$ & ND & $52.59 \pm 2.59$ \\
Ad-Bif-WT & $6.82 \pm 0.22$ & $0.23 \pm 0.06$ & $52.44 \pm 1.09$ & ND & $30.83 \pm 6.64^{\mathrm{B}}$ \\
Ad-Bif-DM & $9.19 \pm 0.43^{\mathrm{A}}$ & $0.44 \pm 0.08$ & $66.32 \pm 1.88^{\mathrm{A}}$ & ND & $28.38 \pm 7.49^{\mathrm{B}}$
\end{tabular}

Liver metabolites were assayed 7 days after adenovirus infusion. Only three animals of each group were chosen, without bias, and used for liver metabolite measurements. Data are mean $\pm \operatorname{SEM}(n=3)$. ${ }^{A} P<$ 0.01 versus $\mathrm{Ad}$-gal. ${ }^{B} P<0.05$ versus $\mathrm{Ad}$-gal. ND, undetectable; Gly, glycogen. 
Table 6

Liver metabolites of saline control mice and diabetic mice treated with adenovirus

\begin{tabular}{lccccc}
\hline & Lac $(\mu \mathrm{mol} / \mathrm{g})$ & $\mathrm{Pyr}(\mu \mathrm{mol} / \mathrm{g})$ & $\mathrm{TG}(\mu \mathrm{mol} / \mathrm{g})$ & $\mathrm{FFA}(\mu \mathrm{mol} / \mathrm{g})$ & $\mathrm{Gly}(\mathrm{mg} / \mathrm{g})$ \\
Saline control & $5.85 \pm 0.57$ & $0.31 \pm 0.02$ & $49.76 \pm 1.36$ & ND & $50.42 \pm 1.55$ \\
STZ-Ad-gal & $3.01 \pm 0.36^{\mathrm{A}}$ & $0.42 \pm 0.03$ & $54.68 \pm 1.20$ & ND & $7.04 \pm 1.95^{\mathrm{B}}$ \\
STZ-Ad-Bif-WT & $8.20 \pm 0.62^{\mathrm{A}, \mathrm{C}}$ & $0.39 \pm 0.03$ & $53.76 \pm 1.46$ & ND & $13.57 \pm 0.44^{\mathrm{B}, \mathrm{D}}$ \\
STZ-Ad-Bif-DM & $9.11 \pm 0.71^{\mathrm{A}, \mathrm{C}}$ & $0.41 \pm 0.08$ & $49.96 \pm 1.24$ & ND & $15.95 \pm 1.42^{\mathrm{B}, \mathrm{D}}$
\end{tabular}

Liver metabolites were assayed 7 days after adenovirus infusion. Only three animals of each group were chosen, without bias, and used for liver metabolite measurements. Data are mean $\pm \operatorname{SEM}(n=3)$. ${ }^{A} P<0.05$ versus saline control. ${ }^{B} P<0.01$ versus saline control. ${ }^{C} P<0.01$ versus $S T Z$-Ad-gal. ${ }^{D} P<0.05$ versus STZ-Ad-gal.

After adenovirus infusion, both normal mice and STZ-induced diabetic mice exhibited increased levels of plasma and liver lactate. This suggests that acceleration of glycolysis or glucose utilization is one mechanism by which increased hepatic F-2,6- $\mathrm{P}_{2}$ reduces HGP and lowers blood glucose levels. Inhibition of gluconeogenesis by increased hepatic F-2,6- $\mathrm{P}_{2}$ may also account for the lower HGP because F-2,6- $\mathrm{P}_{2}$ is an allosteric inhibitor of the key enzyme in gluconeogenesis, fructose-1,6-bisphosphatase. However, it is interesting to note that the mechanism by which overexpressed 6PF-2-K/F-2,6- $\mathrm{P}_{2}$ ase lowers blood glucose appeared to be different in normal as compared to diabetic mice. Thus, in nondiabetic animals, the lowering of blood glucose was accompanied by a decrease in liver glycogen and increased levels of circulating TGs and FFAs, whereas in STZ-diabetic animals, liver glycogen was increased and TG and FFA levels were lowered relative to Ad-gal-treated diabetic animals. These results are consistent with the idea that overexpression of $6 \mathrm{PF}-2-\mathrm{K} / \mathrm{F}-2,6-\mathrm{P}_{2}$ ase activated glycolysis, resulting in diversion of glucose-6-phosphate away from glycogen synthesis into the glycolytic pathway. Alternatively, the hypoglycemia caused by overexpression of 6PF-2-K/F-2,6- $\mathrm{P}_{2}$ ase in normal mice might have induced the degradation of liver glycogen to provide glucose. The increase in circulating TGs and FFAs could either have been a consequence of the fall in insulin/glucagon ratio secondary to hypoglycemia and activation of peripheral lipolysis, and/or de novo lipogenesis in liver induced by enhanced glycolytic flux. Interestingly, overexpression of glucokinase in liver of normal rats also resulted in lowered blood glucose and increased TG and FFA levels, but an increase rather than a decrease in hepatic glycogen stores (26).

In STZ-induced diabetic mice, overexpression of 6PF-2-K/F-2,6- $\mathrm{P}_{2}$ ase also activated glycolysis, as indicated by the increase in lactate levels. However, in these animals, a portion of the glucose-6-phosphate pool was used to synthesize glycogen. The mechanism by which increased levels of F-2,6- $\mathrm{P}_{2}$, a regulator of a distal step in glycolysis, caused glycogen synthesis to increase remains to be investigated. One possibility is that increased F-2,6- $\mathrm{P}_{2}$, along with the distal effect (6 phosphofructo-1 kinase) must also have a stimulatory effect on glucose transport and/or phosphorylation, thereby providing a "push" mechanism that increases the glucose-6-phosphate pool, facilitating glycogen repletion. Indeed, this idea was supported by upregulated glucokinase gene expression in the liver of STZdiabetic mouse, which was caused by increased F-2,6- $\mathrm{P}_{2}$ (our unpublished data). The changes of liver glycogen content in $6 \mathrm{PF}-2-\mathrm{K} / \mathrm{F}-2,6-\mathrm{P}_{2}$ ase overexpressing animals were similar to those in STZinduced diabetic animals after antidiabetic treatments (42-45). However, when compared with glucokinase overexpression $(26,46)$, the lower amount of liver glycogen $(27-32 \%$ of saline control) in STZ-diabetic mice after 6 PF-2-K/F-2,6- $\mathrm{P}_{2}$ ase overexpression indicate that hepatic F-2,6- $\mathrm{P}_{2}$ had less effect on glycogen flux than the glucokinase/glucose-6-phosphatase system, consistent with its a greater metabolic control coefficient on glycogen flux $(47,48)$.

The mechanisms involved in the lipid-lowering effect of $6 \mathrm{PF}-2-\mathrm{K} / \mathrm{F}-2,6-\mathrm{P}_{2}$ ase overexpression in the context of STZ-diabetes are also unknown, but are again similar to what has been observed with glucokinase overexpression (46). In STZ-treated animals, complete insulin deficiency activates peripheral lipolysis, accelerates fatty acid oxidation in liver, and results in a rise in TGs due to esterification of excess fatty acids. Expression of 6PF-2-K/F-2,6- $\mathrm{P}_{2}$ ase in this environment lowers blood glucose, possibly causing a compensatory increase in the rate of fatty acid metabolism in muscle and other peripheral tissues, leading to decreased circulating FFA. This decrease in turn reduces the amount of FFA available for TG synthesis and fatty acid oxidation in liver. If correct, this model suggests that insulin-deficient animals made normoglycemic by hepatic $6 \mathrm{PF}-2-\mathrm{K} / \mathrm{F}-2,6-\mathrm{P}_{2}$ ase overexpression expression may oxidize fatty acids at a higher rate in peripheral tissues than normal animals. Further studies are required to evaluate carefully this possibility and its potential ramifications, both in the presence and absence of basal insulin replacement.

In summary, adenovirus-mediated overexpression of the bifunctional enzyme, 6PF-2-K/F-2,-6- $\mathrm{P}_{2}$ ase, in normal and STZ-induced diabetic mice is capable of modulating hepatic F-2,6- $\mathrm{P}_{2}$. Elevated F-2,6- $\mathrm{P}_{2}$, by regulating HGP, reduces blood glucose. These studies in normal and STZ-induced diabetic mice constitute a proof of principle for a diabetic therapy based on the in vivo manipulation of hepatic F-2,6- $\mathrm{P}_{2}$ levels. These gross manipulations in F-2,6- $\mathrm{P}_{2}$ presented here must still be refined to be able to set an appropriate F-2,6$\mathrm{P}_{2}$ level consonant with the level of hyperglycemia in the diabetic patient.

\section{Acknowledgments}

This work is supported by National Institutes of Health Grants DK-38354 (to A.J. Lange) and DK-58398 
(to C.B. Newgard). The authors thank Gulshan R. Anand for constructive suggestion, and Marla C. Burger and Andrea L. Dopkins for technical assistance.

1. Pilkis, S.J., El-Maghrabi, M.R., Pilkis, J., Claus, T.H., and Cumming, D.A. 1981. Fructose 2,6-bisphosphate. A new activator of phosphofructokinase. J. Biol. Chem. 256:3171-3174

2. Uyeda, K., Furuya, E., and Sherry, A.D. 1981. The structure of "activation factor" for phosphofructokinase. J. Biol. Chem. 256:8679-8684.

3. Van Schaftingen, E., Hue, L., and Hers, H.G. 1980. Fructose 2,6-bisphosphate, the probable structure of the glucose and glucagon-sensitive stimulator of phosphofructokinase. Biochem. J. 192:897-901.

4. Pilkis, S.J., El-Maghrabi, M.R., and Claus, T.H. 1988. Hormonal regulation of hepatic gluconeogenesis and glycolysis. Annu. Rev. Biochem. 57:755-783.

5. El-Maghrabi, M.R., Pate, T.M., Murray, K.J., and Pilkis, S.J. 1984. Differential effects of proteolysis and protein modification on the activities of 6-phosphofructo-2-kinase/fructose-2,6-bisphosphatase. J. Biol. Chem. 259:13096-13103.

6. Okar, D.A., and Lange, A.J. 1999. Fructose-2,6-bisphosphate and control of carbohydrate metabolism in eukaryotes. Biofactors. 10:1-14.

7. Pilkis, S.J., El-Maghrabi, M.R., Pilkis, J., and Claus, T. 1981. Inhibition of fructose-1,6-bisphosphatase by fructose 2,6-bisphosphate. J. Biol. Chem. 256:3619-3622.

8. Van Schaftingen, E., and Hers, H. 1981. Inhibition of fructose-1,6-bisphosphatase by fructose 2,6-biphosphate. Proc. Natl. Acad. Sci. USA. 78:2861-2863.

9. Pilkis, S.J., et al. 1983. Rat hepatic 6-phosphofructo 2-kinase/fructose 2,6bisphosphatase: a unique bifunctional enzyme. Adv. Enzyme Regul. 21:147-173.

10. Van schaftingen, E., and Hers, H.G. 1981. Phosphofructokinase-2: the enzyme that forms fructose-2,6-bisphosphate from fructose-6-phosphate and ATP. Biochem. Biophys. Res. Comm. 101:1078-1086.

11. Pilkis, S.J., Claus, T.H., Kurland, I.J., and Lange, A.J. 1995. 6-Phosphofructo-2-kinase/fructose-2,6-bisphosphatase: a metabolic signaling enzyme. Annu. Rev. Biochem. 64:799-835

12. Nishimura, M., Fedorov, S., and Uyeda, K. 1994. Glucose-stimulated synthesis of fructose 2,6-bisphosphate in rat liver. Dephosphorylation of fructose 6-phosphate, 2-kinase:fructose 2,6-bisphosphatase and activation by a sugar phosphate. J. Biol. Chem. 269:26100-26106.

13. Pilkis, S.J., El-Maghrabi, M.R., McGrane, M., Pilkis, J., and Claus, T.H 1982. Regulation by glucagon of hepatic pyruvate kinase, 6-phosphofructo 1-kinase, and fructose-1,6-bisphosphatase. Fed. Proc. 41:2623-2628.

14. Pilkis, S.J., et al. 1986 . Hormonal modulation of key hepatic regulatory enzymes in the gluconeogenic/glycolytic pathway. Ann. NY Acad. Sci. 478:1-19.

15. Kurland, I.J., el-Maghrabi, M.R., Correia, J.J., and Pilkis, S.J. 1992. Rat liver 6-phosphofructo-2-kinase/fructose-2,6-bisphosphatase. Properties of phospho- and dephospho- forms and of two mutants in which Ser32 has been changed by site-directed mutagenesis. J. Biol. Chem. 267:4416-4423

16. Tauler, A., Lin, K., and Pilkis, S.J. 1990. Hepatic 6-phosphofructo-2kinase/fructose-2,6-bisphosphatase. Use of site-directed mutagenesis to evaluate the roles of His-258 and His-392 in catalysis. J. Biol. Chem. 265:15617-15622

17. Argaud, D., et al. 1995. Adenovirus-mediated overexpression of liver 6 phosphofructo-2-kinase/fructose-2,6-bisphosphatase in gluconeogenic rat hepatoma cells. Paradoxical effect on Fru-2,6- $\mathrm{P}_{2}$ levels. J. Biol. Chem. 270:24229-24236

18. Nordlie, R., Foster, J., and Lange, A. 1999. Regulation of glucose production by the liver. Annu. Rev. Nutr. 19:379-406.

19. Cherrington, A.D. 1999. Banting Lecture 1997. Control of glucose uptake and release by the liver in vivo. Diabetes. 48:1198-1214.

20. Rossetti, L., et al. 1993. Mechanism by which hyperglycemia inhibits hepatic glucose production in conscious rats. Implications for the pathophysiology of fasting hyperglycemia in diabetes. J. Clin. Invest. 102:1126-1134

21. Meyer, C., et al. 1998. Abnormal renal and hepatic glucose metabolism in type 2 diabetes mellitus. J. Clin. Invest. 102:619-624.

22. Bell, P.M., Firth, R.G., and Rizza, R.A. 1986. Assessment of insulin action in insulin-dependent diabetes mellitus using $\left[6-{ }^{14} \mathrm{C}\right]$ glucose, $\left[3-{ }^{3} \mathrm{H}\right] \mathrm{glu}-$ cose, and $\left[2-{ }^{3} \mathrm{H}\right]$ glucose. Differences in the apparent pattern of insulin resistance depending on the isotope used. J. Clin. Invest. 78:1479-1486.

23. DeFronzo, R. 1988. Lilly lecture 1987. The triumvirate: beta-cell, muscle, liver. A collusion responsible for NIDDM. Diabetes. 37:667-687.

24. Okar, D.A., Lee, Y.-H., Argaud, D., McFarlan, S.C., and Lange, A.J. 1998. The 6-phospho-2-kinase/fructose-2,6-bisphosphatase system: regulation by insulin and an insulinomimetic approach to lowering blood glucose levels. In Molecular and cell biology of type 2 diabetes and its complications. F. Belfiore, M. Lorenzi, G.M. Molinatti, and M. Porta, editors. S. Karger AG. Basel, Switzerland. 30-46.
25. Herz, J., and Gerard, R.D. 1993. Adenovirus-mediated transfer of low density lipoprotein receptor gene acutely accelerates cholesterol clearance in normal mice. Proc. Natl. Acad. Sci. USA. 90:2812-2816.

26. O’Doherty, R.M., Lehman, D.L., Telemaque-Potts, S., and Newgard, C.B. 1999. Metabolic impact of glucokinase overexpression in liver: lowering of blood glucose in fed rats is accompanied by hyperlipidemia. Diabetes. 48:2022-2027.

27. Trinh, K.Y., O’Doherty, R.M., Anderson, P., Lange, A.J., and Newgard, C.B. 1998. Perturbation of fuel homeostasis caused by overexpression of the glucose-6-phosphatase catalytic subunit in liver of normal rats. J. Biol. Chem. 273:31615-31620.

28. Lange, A.J., et al. 1994. Isolation of a cDNA for the catalytic subunit of rat liver glucose-6-phosphatase: regulation of gene expression in FAO hepatoma cells by insulin, dexamethasone and cAMP. Biochem. Biophys. Res. Comm. 201:302-309.

29. Murano, K., Inoue, Y., Emoto, M., Kaku, K., and Kaneko, T. 1994. CS-045, a new oral antidiabetic agent, stimulates fructose-2,6-bisphosphate production in rat hepatocytes. Eur. J. Pharmacol. 254:257-262.

30. Van schaftingen, E., Lederer, B., Bartrons, R., and Hers, H.G. 1982. A kinetic study of pyrophosphate: fructose-6-phosphate phosphotransferase from potato tubers. Application to a microassay of fructose-2,6-bisphosphate. Eur. J. Biochem. 129:191-195.

31. Hess, B., and Brand, K. 1974. Methods for animal tissues and micro-organisms. In Methods of enzymatic analysis. Volume 1. H.S. Bergmeyer, editor. Verlag Chemie Weinheim Academic Press Inc. New York, New York, USA/London, United Kingdom. 399-409.

32. Keppler, D., and Decker, K. 1974. Glycogen determination with amyloglucosidase. In Methods of enzymatic analysis. Volume 3. H.S. Bergmeyer, editor. Verlag Chemie Weinheim Academic Press Inc. New York, New York, USA/London, United Kingdom. 1127-1131.

33. Becker, T.C., et al. 1994. Use of recombinant adenovirus for metabolic engineering of mammalian cells. Methods Cell Biol. 43:161-189.

34. Antinozzi, P.A., Berman, H.K., O’Doherty, R.M., and Newgard, C.B. 1999. Metabolic engineering with recombinant adenoviruses. Annu. Rev. Nutr. 19:511-544

35. O'Doherty, R.M., et al. 2000. Activation of direct and indirect pathways of glycogen synthesis by hepatic overexpression of protein targeting to glycogen. J. Clin. Invest. 105:479-488.

36. Colosia, A.D., et al. 1988. Induction of rat liver 6-phosphofructo-2kinase/fructose-2,6-bisphosphatase mRNA by refeeding and insulin. $J$. Biol. Chem. 263:18669-18677.

37. Cline, G.W., Rothman, D.L., Magnusson, I., Katz, L.D., and Shulman, G.I. 1994. ${ }^{13} \mathrm{C}$-nuclear magnetic resonance spectroscopy studies of hepatic glucose metabolism in normal subjects and subjects with insulin-dependent diabetes mellitus. J. Clin. Invest. 94:2369-2376.

38. Neely, P., El-Maghrabi, M.R., Pilkis, S.J., and Claus, T.H. 1981. Effect of diabetes, insulin, starvation, and refeeding on the level of rat hepatic fructose 2,6-bisphosphate. Diabetes. 30:1062-1064.

39. Gil, J., Miralpeix, M., Carreras, J., and Bartrons, R. 1988. Insulin-like effects of vanadate on glucokinase activity and fructose 2,6-bisphosphate levels in the liver of diabetic rats. J. Biol. Chem. 263:1868-1871.

40. Inoue, H., et al. 1994. Insulin-like effects of vanadate on rat liver 6-phosphofructo-2-kinase/fructose-2,6-bisphosphatase mRNA and protein inductions in diabetic rats. Endocr. J. 41:75-82.

41. Miralpeix, M., et al. 1992. Oral administration of vanadate to diabetic rats restores liver 6-phosphofructo-2-kinase content and mRNA. Diabetologia. 35:243-248.

42. Pugazhenthi, S., and Khandelwal, R.L. 1990. Insulinlike effects of vanadate on hepatic glycogen metabolism in nondiabetic and streptozocininduced diabetic rats. Diabetes. 39:821-827.

43. Barbera, A., Rodriguez-Gil, J.E., and Guinovart, J.J. 1994. Insulin-like actions of tungstate in diabetic rats. Normalization of hepatic glucose metabolism. J. Biol. Chem. 269:20047-20053.

44. Khandelwal, R.L., and Pugazhenthi, S. 1995. In vivo effects of vanadate on hepatic glycogen metabolizing and lipogenic enzymes in insulin-dependent and insulin-resistant diabetic animals. Mol. Cell. Biochem. 153:87-94.

45. Short, D.K., Okada, S., Yamauchi, K., and Pessin, J.E. 1998. Adenovirusmediated transfer of a modified human proinsulin gene reverses hyperglycemia in diabetic mice. Am. J. Physiol. 275:E748-E756.

46. Ferre, T., Pujol, A., Riu, E., Bosch, F., and Valera, A. 1996. Correction of diabetic alterations by glucokinase. Proc. Natl. Acad. Sci. USA. 93:7225-7230.

47. Agius, L., Peak, M., Newgard, C.B., Gomez-Foix, A.M., and Guinovart, J.J. 1996. Evidence for a role of glucose-induced translocation of glucokinase in the control of hepatic glycogen synthesis. J. Biol. Chem. 271:30479-30486.

48. Aiston, S., Trinh, K.Y., Lange, A.J., Newgard, C.B., and Agius, L. 1999. Glucose-6-phosphatase overexpression lowers glucose 6-phosphate and inhibits glycogen synthesis and glycolysis in hepatocytes without affecting glucokinase translocation. Evidence against feedback inhibition of glucokinase. J. Biol. Chem. 274:24559-24566. 